\title{
LOS ARABISMOS EN LA HISTORIA LINGÜÍSTICA DEL ESPAÑOL: UNA ESTRATEGIA PARA EL APRENDIZAJE DEL ESPAÑOL Y EL ÁRABE COMO LENGUAS EXTRANJERAS
}

Ali Ibrahim Hasan El-Shboul

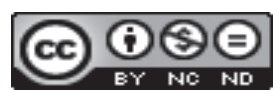

Doi: https://doi.org/10.15517/rfl.v44i2.34696

URL: https://revistas.ucr.ac.cr/index.php/filyling 



\title{
LOS ARABISMOS EN LA HISTORIA LINGÜÍSTICA DEL ESPAÑOL: UNA ESTRATEGIA PARA EL APRENDIZAJE DEL ESPAÑOL Y EL ÁRABE COMO LENGUAS EXTRANJERAS
}

\author{
THE ARABISMS IN THE LINGUISTIC HISTORY OF SPANISH: A \\ STRATEGY FOR THE LEARNING OF SPANISH AND THE ARAB AS \\ FOREIGN LANGUAGES
}

\author{
Ali Ibrahim Hasan El-Shboul
}

\begin{abstract}
RESUMEN
La influencia de la lengua árabe en la española es marcada. Este artículo, que forma parte de una investigación más profunda, estudia los arabismos desde el léxico, lo fonológico, morfológico y sintáctico planteando que quien aprende español o árabe como lengua extranjera tiene en los arabismos una estrategia que facilita tanto el dominio primario de un amplio lenguaje básico como su uso adecuado, ya que conoce y utiliza de manera correcta las reglas que controlan la combinación de los elementos y el dominio de núcleos de indagación temática que hacen atrayente el aprendizaje. Analiza además la manera cómo los arabismos, que surgieron en diferentes épocas de la llegada árabe, aún están vigentes y continúan muy ligados a la vida social de España, por lo cual conocerlos facilita el manejo de las convenciones sociales que controlan el uso de las dos lenguas en distintas situaciones. Se confirma con el artículo que el aprendizaje de los arabismos por parte de los alumnos, les facilita su uso con el mismo significado en que se implantaron y las modificaciones que dicho uso ha tenido facilitando y haciendo más atrayente el aprendizaje de la segunda lengua.

Palabras clave: árabe, español, arabismos, contacto lingüístico, aprendizaje.
\end{abstract}

\begin{abstract}
The influence of the Arabic language on the Spanish language is marked. This article, which is part of a deeper investigation, studies Arabisms from the lexicon, phonological, morphological and syntactic, proposing that those who learn Spanish or Arabic as a foreign language have a strategy in Arabisms that facilitates both the primary domain of a broad basic language as its proper use, since it knows and correctly uses the rules that control the combination of elements and the domain of thematic inquiry centers that make learning attractive. It also analyzes the way in which Arabisms, which arose at different times of the Arab arrival, are still in force and continue to be closely linked to the social life of Spain, so knowing them facilitates the management of social conventions that control the use of both languages in different situations. It is confirmed with the article that the students' learning of Arabicisms facilitates their use with the same meaning in which they were implanted and the modifications that said use has facilitated and making more attractive the learning of the second language.
\end{abstract}

Key words: arabic, spanish, arabisms, linguistic contact, learning.

Dr. Ali Ibrahim Hasan El-Shboul. Universidad de Yarmouk. Departamento de Lenguas Modernas. Profesor de español. Jordania.

Correo electrónico: ali.shboul@yahoo.es

Recepción: 22- 09- 2017

Aceptación: 12- 11- 2017 


\section{Introducción}

Conocer el gran número de arabismos o léxico árabe presente en el español es fundamental para los alumnos españoles y árabes interesados en el aprendizaje del español y del árabe como segunda lengua, lo cual es un camino imprescindible hacia la adquisición de vocabulario que facilite dicho aprendizaje. El presente artículo responde a ese interés y forma parte de una investigación documental mayor sobre una ruta metodológica a partir de los arabismos para facilitar ese aprendizaje.

Se parte de considerar la influencia lingüística del elemento árabe en la formación y desarrollo del español y de lo que hoy se mantiene, habla y escribe, enriqueciendo no solo la adquisición de vocabulario, sino también el nivel morfológico, la adopción de prefijos y sufijos romances para crear nuevas palabras a partir de las raíces árabes, el nivel sintáctico incluyendo la adopción del género de las palabras romances en sus equivalentes árabes y el nivel léxico.

Un aspecto importante son las generalidades que ubican en el tiempo y en las circunstancias el territorio donde surgieron los arabismos. Brevemente se habla del papel auxiliar del diccionario de la RAE y se caracterizan los arabismos haciendo un recorrido por algunos aspectos de las categorías gramaticales iniciando por las consonantes, luego las vocales, los sustantivos, los adjetivos, los verbos, el aspecto contextual en que surgieron los arabismos y las modificaciones en su significación, creando un marco nuevo que facilite el aprendizaje.

Este trabajo aprovecha los aportes de otros estudios y trata de obviar las deficiencias que para el aprendizaje de la lengua extranjera se presentan referidas a la ausencia de diccionarios sobre el tema en las dos lenguas y a la ausencia de información que oriente sobre los cambios semánticos ocurridos, dinamizando el aprendizaje del español como segunda lengua cuya habla está muy extendida y aún mantiene los arabismos.

\section{Generalidades}

Al-Ándalus son los territorios de la Península Ibérica, la isla de Sicilia y los países del norte de África que estuvieron del año 711 al 1492 bajo el poder Islámico, hasta que los Reyes de España tomaron Granada poniendo fin a esta hegemonía.

La llegada de los árabes influyó positivamente el desarrollo de la Península Ibérica en los campos de la organización estatal, la filosofía, la mística, la ciencia, la cultura, las normas sociales, la ganadería, la minería, la agricultura, el urbanismo, la música y el arte. Hubo también otros cambios de gran importancia, que interesan a este artículo, relacionados directamente con el bilingüismo entre el romance vernáculo y el árabe.

Es importante aclarar que se llamaban lenguas romances aquellas que se hablaban en la Península Ibérica y que se derivaron del latín vulgar, lo que hace suponer que existían dos lenguas paralelas: un latín culto y uno vulgar (Marcos Marín, 1984). Ahora, el latín vulgar era el latín vivo y en constante evolución, hablado y no escrito, vuelto dialecto o lengua criolla, o sea, con variantes regionales. El latín culto sólo se utilizaba en la literatura y en la administración de justicia (Fernández, 2011). De esa fragmentación del latín surgieron y perviven el portugués, el gallego, el castellano, el catalán, el francés, el provenzal, el retorromano, el italiano, el sardo y el rumano.

El castellano o español es la lengua romance que interesa a este artículo. Como comenta Rincón Castellanos (2012) es la más hablada en el mundo debido a la expansión dada con el descubrimiento de América. Se cree que surgió en el primitivo reino de Castilla y tiene en la actualidad variantes dialectales en América cercanas a la variante hablada en Al-Ándalus, 
con la que comparte el seseo o el yeísmo; y al canario, además de una variante judeoespañola hablada por los sefardíes descendientes de los judíos expulsados de España en 1492.

Con los árabes llegó una lengua de naturaleza distinta a las románicas: la árabe, con sus diferentes manifestaciones escritas y orales, que se impuso como lengua oficial y de cultura. Esa lengua actuó como superestrato del romance andalusí y como adstrato, ya que al compartir con el español el área geográfica influyó sobre él. Siendo muchos los que dominaban ambas formas lingüísticas, Al-Ándalus fue una sociedad bilingüe al menos hasta el siglo XI o XII.

Al-Ándalus se vio inmersa en un nuevo proceso cultural. Junto al árabe coloquial o al escrito, la población continuaba utilizando el romance hispánico mozárabe cuyo nombre se deriva del árabe andalusí o musta'rabí hablado en Al-Ándalus, que era territorio de la Península Ibérica, y este, a su vez, del árabe clásico musta'rab, o árabe culto que era utilizado en algunos textos (Glick, 1991, p. 43). El mozárabe era:

la variedad lingüística románica hablada en Al-Ándalus, especialmente hasta finales del siglo XI, no sólo por los cristianos que permanecieron en territorio musulmán, sino también por los muladíes o conversos al Islam y, en menor medida, por parte de la población conquistada (Galmes de Fuentes, 1958, p. 47)

Los árabes se referían al mozárabe como ayamiya o aljamía que era la lengua de extranjeros, aunque esa denominación podía aplicarse a cualquier lengua no arábiga. El árabe actuó como lengua dominante con un conjunto de características fonéticas, gramaticales y léxicas que se impusieron a partir del año 711 por encima de las lenguas de otros grupos minoritarios como bereberes y sirios, que llegaron al mismo tiempo que ellos, y sobre cuyas lenguas actuó como adstrato. Es innegable la existencia de este periodo bilingüe, no sólo por la gran cantidad de arabismos en el romance, sino por las constantes interferencias romances que aparecen en las composiciones árabes: muwashahat, jarchas y zégeles (Corriente, 1997).

Con la llegada de los árabes al actual territorio de España, pasó a llamarse Al-Ándalus. Sus costumbres, cultura y lengua recibieron la influencia de ese grupo poblacional. Los árabes llegaron por etapas (Toro Lillo, 2006): en el 711 se asentaron en las ciudades de Écija, Jaén y Sevilla; en Mérida y Toledo en el 713; en Zaragoza en el 714 y en la zona de Cataluña entre 716 y 719. Del 711 al 755 crearon el Emirato de Damasco; del 756 al 929, luego de estar debilitada su población, se reforzaron y crearon el Califato de Córdoba alcanzado la España musulmana su máximo esplendor. Entre 1086 y 1140 ya la presencia árabe era decadente y en 1492 se redujo ostensiblemente.

Conocer en profundidad el mozárabe es tarea difícil debido a la falta de documentación. La caracterización que se hace en este artículo es posible gracias a los rasgos que se deducen de diferentes fuentes: glosarios latino-árabes o hispano-árabes, tratados de medicina o botánica y restos literarios. Esa misma situación dificulta la delimitación de la influencia que pudo tener sobre las otras lenguas peninsulares. A pesar de que el mozárabe parece que compartió algunos rasgos con otros dialectos, las fronteras linguiísticas de la Península fueron marcadas por la expansión de los reinos cristianos y, aunque había hablantes que dominaban las dos lenguas, las diferencias lingüísticas entre ellas eran tan grandes que el influjo quedó en los aspectos más externos, sobre todo en el léxico.

El periodo bilingüe al que se hace referencia en este artículo está probado con la gran cantidad de arabismos en el romance y por las constantes interferencias romances que aparecen en los muwashahat, que son composiciones poéticas, cuyo estilo y tono eran cultos y refinados, de varias estrofas de cinco o más versos en árabe clásico terminadas con una estrofa en mozárabe llamada jarcha, que servía de estrofa de remate (Harlan, 2014). 
Por su parte, las jarchas son composiciones populares breves de carácter amoroso relacionadas con la lírica primitiva hispánica de origen popular, como las cantigas de amigos y los villancicos. Tienen un estribillo de dos versos, al que siguen otros sonidos acompasados que a su vez tienen una rima compuesta por un sonido acompañado de otros tres versos, o mudanza, y un cuarto verso, o vuelta, que rima con los sonidos acompasados pertenecientes al estribillo o repetición. La distribución de la rima es la siguiente: aa (estribillo), bbb (mudanza), a (vuelta) y repetición del estribillo (Ariza, 2004, p. 24).

La escritura del mozárabe en el ámbito público se hacía con aljamía, es decir, con árabe clásico o musta'rab, arabizado. En el ámbito privado usaban sus dialectos romances, si bien muy influidos por el idioma árabe. Esa coexistencia de dos lenguas en una misma comunidad, con ámbitos de uso diferentes para cada una, conocida como diglosia, dejó su huella en las posteriores lenguas romances peninsulares en forma de un superestrato árabe en el vocabulario (Wikipedia, s.f.).

Como se deduce de lo anterior, los arabismos son las palabras procedentes del árabe que están incorporadas al español. Según el DRAE, son los giros o modos de hablar propios de la lengua árabe o los vocablos de la lengua árabe empleados en otra. También se denominan arabismos a las disciplinas científicas que se ocupan del estudio de la lengua y cultura árabe. Pocos arabismos proceden originalmente de otra lengua, por ejemplo, la persa. La lengua mozárabe era una mezcla de cuarenta por ciento de términos árabe-bereberes y sesenta por ciento de vocablos romances (Sola Solé, 1973), siendo mucho más frecuentes dentro de la parte del vocabulario oriental los sustantivos frente a los verbos.

En español existen numerosos arabismos, muchos de uso muy frecuente, influencia que es muy notable. Un número tan elevado de palabras se explica por la necesidad de nombrar objetos y tareas que trajeron los árabes a la península y por el prestigio que entonces tenía una cultura tan avanzada. Los arabismos abarcan casi todos los campos de actividad humana y son, después del latín, el caudal léxico más importante del español, al menos hasta el siglo XVI (González, 2015, p. 1). En la actualidad hay aproximadamente cuatro mil palabras árabes en el español. La RAE (2014) dice que el léxico del español contiene unos noventa y tres mil vocablos y de ellos el ocho por ciento, lo que equivale a siete mil cuatrocientas cuarenta palabras, son de origen árabe.

\subsection{La adquisición de vocabulario y léxico por parte de los alumnos}

La adquisición del vocabulario por los aprendices de lenguas extranjeras, el español para los árabes en este caso, pasa a nivel universitario por múltiples posibilidades pedagógicas. Merece especial atención el conocimiento de la vía de transmisión de los arabismos como parte integrante del léxico español que es objeto del estudio. Lo primero es diferenciar brevemente léxico y vocabulario:

como término lingüístico general, la palabra léxico designa el conjunto de las unidades que forman la lengua de una comunidad, de una actividad humana, de un hablante. La estadística léxica opone léxico y vocabulario: el término léxico se reserva entonces para la lengua y el de vocabulario para el habla. Las unidades del léxico son los lexemas, mientras que las unidades del habla son los vocablos y las palabras (la palabra designa toda ocurrencia de un vocablo cualquiera) (Dubois, et al, 1979, p. 389)

El léxico es el caudal de voces, modismos y giros de un conjunto de las palabras de un idioma, o de las que pertenecen al uso de una región, a una actividad determinada (RAE, 2001); 
el vocabulario por su parte es el conjunto de palabras de un idioma. Al pertenecer el léxico a una comunidad geográfica determinada, cada uno de sus habitantes debe conocerlo, lo que quiere decir que el léxico está en la memoria de cada habitante en su región; el vocabulario lo posee cada persona en particular y lo utiliza en su acto comunicativo (Moliner, 1998).

Para los propósitos del aprendizaje del español y del árabe como lengua extranjera es importante que el alumno tenga claro, por una parte, que el vocabulario abarca seis categorías disponibles que son las siguientes:

- movilidad inmediata, porque puede utilizarse espontáneamente según las necesidades derivadas de la producción lingüística;

- frecuente, porque es el utilizado varias veces en una sola conversación;

- $\quad$ pasivo, que es el que el aprendiz entiende sin ayuda o con muy poca ayuda, pero no es capaz de utilizar autónomamente;

- activo, que es el que el aprendiz comprende sin problemas y es capaz de utilizar cuando lo necesita sin necesidad de ayuda;

- $\quad$ usual, que es el que practican la mayoría de las personas del grupo social;

- $\quad$ específico, que exige exactitud y precisión. (Galisson, 1979)

Por otra, que el léxico está compuesto por:

- palabras raíces, formadas por un único lexema;

- palabras derivadas, formadas por un lexema al que se añaden uno o varios morfemas;

- palabras compuestas, formadas por más de un lexema pero que expresan un solo referente;

- unidades mayores;

- lexías complejas, conformadas por más de una palabra, las cuales sintácticamente no se comportan como palabras compuestas y están fosilizadas, es decir, no se separan. Algunas tienen una significación muy clara, otras son semitransparentes y unas más totalmente opacas en relación a las palabras que las componen.

Hay además expresiones léxicas:

- de sintaxis fija;

- anquilosadas;

- frases hechas conversacionales;

- fórmulas fijas para iniciar, mantener o acabar la conversación, o para reaccionar a lo que dice el interlocutor. (McCarthy y O’Dell, 2010)

Se considera que para los aprendices es imprescindible el conocimiento de los arabismos de estos tipos y la mayor o menor fosilización sintáctica porque constituyen una parte muy importante de la lengua española y tienen una gran relevancia en el proceso de adquisición de la lengua y en el acto comunicativo.

Como parte del aprendizaje, los alumnos de lengua extranjera española deben además conocer sobre el contexto sociopolítico e histórico donde se desarrolló y desarrolla la lengua, pero también y fundamentalmente deben discutir en clases el contexto lingüístico en el que se engarzan los préstamos árabes en español. Para ello, se requiere que tomen conciencia de que a lo largo de la historia el léxico se ha ido incrementando. De hecho, cuando descubran que el léxico español presenta numerosos préstamos de la lengua árabe, su interés se acrecentará 
porque logran entender que la cultura española, así como la árabe, ha tenido gran importancia en el desarrollo de la lengua.

Otro paso importante en el aprendizaje de vocabulario y léxico árabe en la lengua española es que los aprendices destaquen el esplendor y la importancia del legado árabe que se introdujo en el mundo hispánico a través de España. Distinguirán así, dentro de la lista de préstamos y textos, los vocablos relativos a lo científico, lo cultural, lo institucional, lo arquitectónico, lo comercial, lo cotidiano y una buena parte de los topónimos de las regiones del sur de España. De la misma manera identificarán vocablos resultado de la mezcla de elementos cristianos, judíos, árabes y otro tipo de arabismos propios de los romances hispánicos que hacen referencia a las labores o tareas agrícolas, las plantas, los frutos, la alimentación, las flores, la artesanía, el comercio, las instituciones, el vestido, los juegos y oficios en general. Algunos de esos arabismos se remontan a orígenes distintos, por ejemplo: ajedrez de la lengua persa y alquimia de la lengua griega, en los cuales lo que los árabes hicieron fue continuar su labor de transmisores de cultura.

\subsection{El Diccionario de la Real Academia Española, instrumento de aprendizaje de los arabismos}

Para conocer el léxico de origen árabe en la lengua española y el abundante vocabulario procedente de antiguos prestamos, el Diccionario de la Real Academia Española es considerado el pilar fundamental y la mejor fuente de estudio de la evolución de la lengua española. La institución de la Real Academia Española, RAE, se fundó en el año 1713 con el objetivo principal de mantener la unidad linguiística del castellano. Desde la primera edición del Diccionario Académico, editado por Francisco del Hierro en Madrid entre los años 1726 y 1739, hasta la última edición (García de la Concha, 2014), se ha mantenido la función del diccionario como herramienta normativa y descriptiva de la lengua.

El diccionario es un extraordinario depósito de riqueza lingüística. Sin duda las cuestiones relativas a la adquisición de nuevo léxico se estudian de forma excepcional en él, ya que contiene un repertorio general por excelencia de las voces que componen la lengua (Álvarez de Miranda, 1995). El conjunto de palabras con que cuenta la lengua española no es fijo ni estable y desde el primer diccionario de Nebrija en 1492 hasta los textos más recientes, la lexicografía española se ha esforzado en explicar, no sólo la historia de las voces castellanas más acreditadas de su vocabulario patrimonial, sino también las de las nuevas palabras que han ido llegando a la lengua.

El diccionario hace un reconocimiento a través del léxico de la importancia del elemento árabe en el español, sobre todo porque "el elemento árabe fue, después del latín el más importante del vocabulario español hasta el siglo XVI” (Lapesa, 1980, p. 145). El diccionario se encarga de realizar por primera vez la divulgación de muchos arabismos al castellano, sobre todo en campos científicos como la técnica, que es muy específica del conocimiento humano (Pavón Maldonado, 1977), la medicina (Vázquez de Benito et al., 1989), la anatomía, la farmacia, la botánica, la arquitectura, la música, las matemáticas y la astronomía (Ammadi, 2010). 


\section{Categorías gramaticales de los arabismos}

\subsection{Sistema fonético y fonológico}

Tratándose este artículo de un acercamiento amplio a una investigación diacrónica mayor sobre la influencia de una lengua, en este caso el árabe, sobre otra, el español, influencia que se conoce como arabismo, es fundamental tratar brevemente las categorías gramaticales del árabe, sobre todo cuando la intención es pedagógica. Lo primero entonces es resaltar que cuando los alumnos aprenden la segunda lengua, en el caso de ser hablantes de árabe, lo primero que deben hacer frente al léxico es adaptar el sistema fonético y fonológico para realizar correctamente la pronunciación de los arabismos, ya que las diferencias con el español son grandes; es decir, deben reproducir los arabismos de acuerdo con las reglas del español (Lastra, 1992). Ese acto dará lugar a un proceso de acomodación lingüística que siempre ha de estar presente en la situación de contacto. Para evidenciarlo se muestran los siguientes ejemplos en el Cuadro 1.

\begin{tabular}{|l|l|}
\hline algodón & al-qutun \\
\hline alfombra & al-humra \\
\hline alcoba & al-qubbah \\
\hline aldea & al-dayah \\
\hline alcalde (equiparado con juez) & al-qadi \\
\hline albóndiga & al-bunduqa \\
\hline
\end{tabular}

Cuadro 1. Proceso de acomodación lingüística de las lenguas árabe y español

En segundo lugar, deben hacer un recorrido -vital para aprendices de cualquiera de las dos lenguas en cita- sobre consonantes y vocales en árabe, lo que les facilita comprender los arabismos y todo lo relacionado con fonética y morfología.

\subsubsection{Las consonantes}

Para comprender mejor lo que se expondrá a continuación, es necesario enfatizar en la clasificación de las consonantes de la siguiente manera (Millar, Salgado y Zedán, 2005, pp. 30-32):

- Obstruyentes que son las que se pronuncian mediante una obstrucción considerable a la salida del aire. Se clasifican en:

- $\quad$ sordas: $/ p /,|t|, \mid \mathrm{k} /$;

- sonoras oclusivas orales o explosivas: $/ b /, / d /, / g /$;

- africadas que comienzan oclusivas y luego sueltan el aire: $/ \mathrm{ch} /, \mid \mathrm{t} /$;

- fricativas con una fricción en el punto de articulación sin interrumpir la salida del aire: $|f|,|s|,|y|,|z|$.

- Sonantes o resonantes que son sonoras. Se clasifican en nasales:

- líquidas que se articulan con el tracto abierto y, aunque existe algún obstáculo, este no impide la salida del aire por los espacios que deja libres;

- laterales que dejan salir el aire por uno o dos costados de la lengua: $/ l /$.

- Con excepción de los chasquidos consonánticos (clics), todas las consonantes doblemente articuladas son labial-velares, pero hay un gran número de consonantes 
coarticuladas con articulaciones secundarias, las más frecuentes de labialización, como en $\left[\mathrm{k}^{\mathrm{w}}\right]$ y defaringalización que es la pronunciación de una consonante coarticulada con articulación secundaria como la que ocurre con las consonantes enfáticas como [ $\left.\mathrm{t}^{ }\right]$ (Wikipedia, s.f.).

El número de consonantes en el árabe es mayor que en el español y los fonemas, como es de suponer, poseen características que no existen en este último idioma. Así lo muestra el siguiente cuadro (Grossman, 1969, p. 59) sobre la adaptación de los fonemas árabes al sistema fonológico del romance. Como se ve en el cuadro, en la serie de las oclusivas $/ t / \mathrm{y} / d /$ tienen sus correspondientes enfáticas $/ t / /^{\prime}$ y $/ d / /^{\prime}$. En romance no existía la glotal $/ i /$ mientras que la uvulovelar árabe $/ q /$ no tenía su correspondiente en romance. Las fricativas árabes $/ s /$ y $/ z /$ también poseen sus correspondientes enfáticas $/ S /$ y $/ z /$; las velares $/ j / \mathrm{y} / g / \mathrm{y}$ las laríngeas $/ 1 / \mathrm{y}$ /1'1/ no existían en romance. El árabe, en cambio, posee solo la africada /j/.

Hay que enfatizar además que, en algunos aspectos, el mozárabe es más arcaico que el español. Uno de esos aspectos es la preservación tanto de los grupos consonánticos prestados del latín $/ C L /, / F L /, / P L /$, como de las consonantes sordas intervocálicas $/ P /$, $/ T /, / C /$, caso que se da en las palabras lopa (loba), toto (todo), y formica (hormiga). Como dice Millar, "de la escritura solo forman parte las consonantes y las vocales largas" (1998, p. 787). Según la misma autora, "las consonantes enfáticas se articulan curvando la parte posterior de la lengua, para aproximarla al velo del paladar, manteniendo la parte anterior de la lengua en posición apical o sibilante" (1998, p. 787). Véanse los Cuadros 2, 3 y 4.

\begin{tabular}{|c|c|c|c|c|c|c|c|c|c|c|c|c|c|}
\hline & \multicolumn{13}{|c|}{ Tipo de pronunciación } \\
\hline \multirow{2}{*}{$\begin{array}{l}\text { Tipo } \\
\text { Sonoridad }\end{array}$} & \multicolumn{2}{|c|}{ Labiales } & \multicolumn{2}{|c|}{ Labiodentales } & \multicolumn{2}{|c|}{$\begin{array}{l}\text { Dentales } \\
\text { alveolares }\end{array}$} & \multicolumn{2}{|c|}{ Prepalatales } & \multicolumn{2}{|c|}{ Palatales } & \multicolumn{2}{|c|}{ Velares } & \\
\hline & sor. & son. & sor. & son. & sor. & son. & sor. & son. & sor. & son. & sor. & son. & \\
\hline \multirow[t]{2}{*}{ Oclusivas } & $\mathrm{p}$ & $\mathrm{b}$ & & & $\mathrm{t}$ & d & & & & & $\mathrm{k}$ & $\mathrm{g}$ & $\begin{array}{l}\text { No } \\
\text { suenan }\end{array}$ \\
\hline & \multicolumn{2}{|l|}{$\mathrm{m}$} & & & \multicolumn{2}{|l|}{$\mathrm{n}$} & & & & \multicolumn{2}{|l|}{$\mathrm{n}$} & & \multirow[t]{2}{*}{ Sonantes } \\
\hline \multirow[t]{2}{*}{ Fricativas } & & & & & & & & & & & & & \\
\hline & & & f & & $\mathrm{s}$ & $\mathrm{z}$ & $(\mathrm{z})$ & & & & & & \multirow{2}{*}{$\begin{array}{l}\text { no } \\
\text { suenan }\end{array}$} \\
\hline Africadas & & & & & ls & $\mathrm{dz}$ & ${ }^{\prime} c^{\prime}$ & & & & & & \\
\hline
\end{tabular}

Cuadro 2. Los fonemas árabes adaptados al sistema fonológico romance

\begin{tabular}{|c|c|c|c|c|c|c|c|c|c|c|c|c|c|}
\hline & \multicolumn{13}{|c|}{ Tipo de pronunciación } \\
\hline \multirow{2}{*}{$\begin{array}{l}\text { Tipo } \\
\text { Sonoridad }\end{array}$} & \multicolumn{2}{|c|}{ Labiales } & \multicolumn{2}{|c|}{ Labiodentales } & \multicolumn{2}{|c|}{$\begin{array}{l}\text { Dentales } \\
\text { alveolares }\end{array}$} & \multicolumn{2}{|c|}{ Prepalatales } & \multicolumn{2}{|c|}{ Palatales } & \multicolumn{2}{|c|}{ Velares } & \\
\hline & sor. & son. & sor. & son. & sor & son. & sor. & son. & sor. & son. & sor. & son. & \\
\hline \multirow[t]{2}{*}{ Oclusivas } & $\mathrm{p}$ & $\mathrm{b}$ & & & $\mathrm{t}$ & d & & & & & $\mathrm{k}$ & $\mathrm{g}$ & $\begin{array}{l}\text { No } \\
\text { suenan }\end{array}$ \\
\hline & \multicolumn{2}{|l|}{$\mathrm{m}$} & & & \multicolumn{2}{|l|}{$n$} & & & & \multicolumn{2}{|l|}{$\mathrm{n}$} & & \multirow[t]{2}{*}{ Sonantes } \\
\hline \multirow[t]{2}{*}{ Fricativas } & & & & & & & & & & & & & \\
\hline & & & $\mathrm{f}$ & & $\mathrm{s}$ & $\mathrm{z}$ & (z) & & & & & & \multirow{2}{*}{$\begin{array}{l}\text { No } \\
\text { suenan }\end{array}$} \\
\hline Africadas & & & & & 1s & $\mathrm{dz}$ & $\mathrm{c}^{\prime}$ & & & & & & \\
\hline
\end{tabular}

Cuadro 3. Las consonantes árabes actuales 


\begin{tabular}{|c|c|c|c|}
\hline Sonido & Nombre & Sonido & Nombre \\
\hline$\overline{\mathbf{a}}$ & alif & $\underline{\mathbf{d}}$ & ḍād \\
\hline b & $b \bar{a}$ & $\mathbf{t}$ & tā \\
\hline $\mathbf{t}$ & ta & $\underline{\mathbf{d}}$ & $\widehat{\mathrm{d}} \mathrm{h} \overline{\mathrm{a}}^{\prime}$ \\
\hline th & tha & $\because$ & 'ay \\
\hline $\mathbf{j}$ & ğīm & gh & ghayn \\
\hline ḥ & hạa & f & fā \\
\hline $\mathbf{k h}$ & khā & g & gāf \\
\hline d & dāl & $\mathbf{k}$ & kāf \\
\hline ḍ & dhāl & 1 & lām \\
\hline $\mathbf{r}$ & rā & $\mathbf{m}$ & mīm \\
\hline $\mathbf{z}$ & zāy & $\mathbf{n}$ & nūn \\
\hline $\mathbf{s}$ & šīn & $\mathbf{h}$ & hâ' \\
\hline sh & šhīn & $\mathbf{w}(\mathbf{u})$ & wāw \\
\hline$\underline{\mathbf{S}}$ & șād & $\mathbf{y}(\mathbf{i})$ & yā \\
\hline
\end{tabular}

Cuadro 4. Los grafemas consonánticos

Cabe destacar que la conservación del carácter sordo o sonoro de los fonemas árabes, una vez adaptados, siguió la evolución de los españoles, sin embargo, hay una serie de fenómenos que merece la pena destacar para poder entender la acomodación de ciertos fonemas árabes no existentes en el español.

- Alarde, algib> aljibe (Steiger, 1932);

- las consonantes aspiradas árabes se asimilaron con la única aspirada romance, la [h], alófono de $/ f /$, y produjeron diferentes resultados: o bien se representaron por [h] (alharaca, alheña), o bien fueron reemplazadas por /f/. De ahí las alternancias en algunas formas: rahal/rafal, AlhambralAlfombra, alholilalfolí;

- en otros casos dieron como resultados /g/ o /k/: al-'arabiyya > algarbía;

- a veces llegaron a desaparecer (sobre todo el 'ain árabe): 'arab > árabe, al-'arif > alarife (Maíllo, 1991);

- las terminaciones de los masculinos árabes eran consonantes o grupos consonánticos no admitidos por el español desde el siglo XIV. En estos casos, el romance añadió una vocal de apoyo: $s u c q>$ zoco;

- los nombres árabes terminados en vocal acentuada eran insólitos en español, por ello se colocó una consonante paragógica, asimilando así su forma a los sustantivos habituales en español: alquilé > alquiler, al-banna '’ > albañí > albañil (Corriente, 1991);

- las consonantes geminadas árabes que poseen rasgo distintivo fueron interpretadas por los mozárabes como consonantes simples, debido a que el romance no conservó la correlación de cantidad presente en el latín. Frente a un vocablo en cuyo interior aparecía una consonante germinada, el hablante, desconociendo el fenómeno, automáticamente producía una simplificación. Lo mismo ocurría en palabras que, comenzando con una de las consonantes solares, se definían con la $u$; en estos casos 
se produce asimilación fonética de $/ l /$ a la respectiva consonante solar inicial, lo que da origen en árabe a una germinación que equivale a una simplificación en romance (Millar, 1998). Véase Cuadro 5.

\begin{tabular}{|c|c|}
\hline Español & Árabe \\
\hline almohada & al-mujadda \\
\hline azúcar & as-sukkar \\
\hline acicate & as-siqat \\
\hline
\end{tabular}

\section{Cuadro 5. Consonantes germinadas en árabe y simplificadas en español}

- Las consonantes germinadas $/ l l /, / n n / /, / d d / \mathrm{y} / \mathrm{rr} /$, fueron interpretadas como simples, lo mismo que aquellas que se iniciaban con /al/ en las que hubo asimilación fonética con la /l/ y palatalización que es un modo de articulación especial en el cual un fonema o sonido desplaza su punto de articulación hasta la región palatal o palato-alveolar debido a la cercanía de una vocal (u otro sonido) de articulación palatal. Véase Cuadro 6.

\begin{tabular}{|l|l|}
\hline \multicolumn{1}{|c|}{ Español } & \multicolumn{1}{c|}{ Árabe } \\
\hline almohada & al-mujadda \\
\hline albañil & al-banni' \\
\hline arroz & ar-ruzz \\
\hline argolla & añ-gulla \\
\hline
\end{tabular}

Cuadro 6. Consonantes germinadas que se palatizaron

- Las consonantes oclusivas enfáticas árabes $/ t /$ y $/ \underline{d} /$ y las fricativas $/ s ̣ /$ y $/ z ̧ /$ que no tenían correspondiente en romance también se palatalizaron. Véase Cuadro 7.

\begin{tabular}{|l|l|}
\hline azote & as-saw \\
\hline azúcar & as-sukkar \\
\hline arrayán & ar-rayhān \\
\hline
\end{tabular}

Cuadro 7. Consonantes palatalizadas

- A ello se suma que, una vez admitidos, los arabismos sufrieron los mismos cambios fonéticos que el romance en la palatalización de geminadas: an-nil > añil (RAE, 2014). Este cambio afectó incluso a los topónimos latinos: lat. Caesar Augusta> ár. Saraqusta $>$ Çaragoça $>$ Zaragoza; y a la sonorización de las oclusivas sordas intervocálicas: al-qutun > algodón (Steiger, 1932).

Entre los tratamientos consonánticos de valor (Abad, 1986) se mencionan también

- La conservación de la f- inicial;

- $\quad$ g-, j- iniciales convertidas en y- o ch- ante vocal palatal;

- 1- palatalizada en lengua /lingual

- ce, ci cambiados en una africada sorda. 


\subsubsection{Las vocales}

El sistema vocálico árabe tiene tres fonemas $/ a, i, u /$, dos categorías de abertura y distinción de cantidad y se acomodó al del romance con tres grados de abertura perdiendo la función distintiva de cantidad (Steiger, 1932).

- $\quad$ El diptongo au $>$ o (as-saut $>$ azote $)$

- $\quad$ El diptongo ai > e (mais > almez)

Los vocalismos árabes son (De Urioste, 2001):

- diptongación de /o/ breve tónica en /ue/, en los topónimos: Opta > Heute. Las vacilaciones /ue/, /uo/, /o/ eran abundantes en Andalucía: royuela, royuola, royola (una planta);

- $\quad$ diptongación de /e/ breve tónica:

- en inicial vacila entre -ja-, -ie-: hěrba > yarba, yerbac

- cuando no es inicial es más frecuente la ausencia del diptongo: mielca, frente a lebre, pede, terra, bono;

- dos derivados del sufijo - ěllu presentan cuatro formas:

- ello: tomello (tomillo);

- iello: tomiello (tomillo);

- iel: cariel (cardillo);

- el: Alconchel (nombre de pueblo);

- $\quad$ a veces, se da la reducción -iello $>$-illo: tomiello $>$ tomillo;

- diptongación de /o/ breve ante yod: Úculu > welyo (ojo);

- vacilación entre la conservación o pérdida de la -o final:

- lop forn

- lupu furnu

- lopo forno

- conservación de los diptongos decrecientes:

- pandair (pandero);

- escalaira (escalera);

- sabatair (zapatero)

Reiterando lo anterior, solo existen tres vocales en árabe, llamadas también vocales largas, que sirven en la mayoría de los casos para prolongar la pronunciación o acentuar la palabra en la sílaba en la que se encuentran estas vocales, pero se comenta que existen también otras vocales, llamadas breves, que se escriben encima o debajo del resto de las letras. Muchas veces en los textos árabes estas vocales no se escriben, por lo que es fundamental el estudio de la gramática y un buen conocimiento de vocabulario básico para poder leer un texto que no contenga las vocales cortas. En los arabismos están presentes:

- el fatha: es una rayita que se escribe encima de la letra y toma el sonido de $/ a /$ :

- $\quad$ gَ- ua, ऽ-da, بَ- ba;

- el kasra: es una rayita que se escribe debajo de la letra y toma el sonido de $/ i$ : ن - ni, o - di, ف - fi;

- $\quad$ el damma: es como una g pequeñita que se coloca encima de la palabra y toma el sonido de $/ u /:$ - tu, j - lu, $ُ$ - uu (prolongar el sonido de la u);

- $\quad$ el sukun: véase Cuadro 8. 


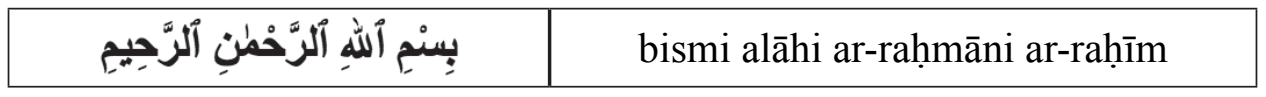

Cuadro 8. El Sukun o la falta de vocal

Este último signo ortográfico no es en sí una vocal corta. Es más como un cero que indica ausencia de vocal. Cuando aparece, como en el gráfico, encima de la letra, quiere decir que esa letra no tiene vocal. En la palabra / grosa la /r/ lleva sukun y no lleva vocal, por lo tanto se leería /ua-r-da-tun/

- El tanuin: las vocales breves duplicadas se denominan "tanuin" y aparecen siempre al término de la palabra. Se leen así:

-la fatha duplicada se lee /an/;

-la kasra duplicada se lee /in/;

-la damma duplicada se lee /un/. Véase Cuadro 9.

\begin{tabular}{|c|c|}
\hline بَيْتِ & bait-in \\
\hline شُكُرَراً & shukr-an \\
\hline وَزْدَة & shukr-an \\
\hline
\end{tabular}

Cuadro 9. Ejemplos del tanuin

Es importante mencionar los rasgos de la vocalización (Abad, 1986):

- diptongación en /e/ y /o/ breves tónicas y ante yod;

- mantenimiento de los diptongos decrecientes /aiY/ y /au/ y de los estadios /ei/ y /ou/;

- conservación de la vocal /o/ en posición final;

- diptongación de /o/ breve tónica en /uel en los topónimos: Opta > Heute. Las vacilaciones /uel, /uo/, /o/ eran abundantes en: royuela, royuola, royola (una planta)

\subsubsection{Los sustantivos}

Los alumnos de español o árabe como lengua extranjera deben aprender la estructura de los sustantivos en árabe porque está presente en todas las conversaciones denotando personas, lugares, cosas, animales e ideas, o sirviendo gramaticalmente como sujeto de una oración, objeto de un verbo u objeto de una preposición. Así mismo no deben olvidar que en relación con su género, los artículos y los adjetivos utilizados con ellos cambian. A eso se denomina concordancia de género, es decir, que los sustantivos femeninos requieren artículos en la forma femenina (Giol y Soldevilla, 1983). En el caso del español se conservan alrededor de cuatro mil sustantivos entre los arabismos y abarcan una extensa gama de campos semánticos (Mikinasi, 1963). Véanse los Cuadros 10 a 19.

\begin{tabular}{|l|l|}
\hline Arabismo & Transcripción \\
\hline aceite & al.zaīt \\
\hline aceituna & al-zaytūn \\
\hline albaricoque & al-barqūq \\
\hline
\end{tabular}


ALI EL-SHBOUL: Los arabismos en la historia lingüística...

\begin{tabular}{|l|l|}
\hline albóndiga & Al-būnduq \\
\hline alcachofa & jūršūf \\
\hline acebibe & zabīb \\
\hline alubia & al-lūbīa \\
\hline arroz & al-rrūz \\
\hline azafrán & Al-za'farān \\
\hline azúcar & al-sukar \\
\hline berenjena & bādeñjān \\
\hline albacora & Al-bākūrah \\
\hline espinacas & sabānej \\
\hline limón & līmūn \\
\hline
\end{tabular}

Cuadro 10. Sustantivos culinarios, de agricultura, horticultura y pesca

\begin{tabular}{|l|l|}
\hline Arabismo & Transcripción \\
\hline albogue & albūq \\
\hline guitarra & qītarah \\
\hline laúd & al'ūd \\
\hline ajabeba & šabābah \\
\hline atabal & ațṭbál \\
\hline tambor & tanbur \\
\hline zambra & zámmarah \\
\hline
\end{tabular}

Cuadro 11. Sustantivos de instrumentos musicales y danzas

\begin{tabular}{|l|l|}
\hline Arabismo & Transcripción \\
\hline ajuar & al-šūar \\
\hline albornoz & al-burnūs \\
\hline alpargata & al-baqah \\
\hline babucha & bābūj \\
\hline mandil & mand̄̄l \\
\hline
\end{tabular}

Cuadro 12. Sustantivos de vestimenta, calzado y ropa de hogar 


\begin{tabular}{|l|l|}
\hline Arabismo & Transcripción \\
\hline aduana & al-dīwāneh \\
\hline aldea & addāy'ah \\
\hline alquiler & al-karrā' \\
\hline arrabal & al-rabḍā \\
\hline ataúd & tābūt \\
\hline barrio & tarrāā \\
\hline mazmorra & mațmarah \\
\hline
\end{tabular}

Cuadro 13. Sustantivos de instituciones administrativas y sociales

\begin{tabular}{|l|l|}
\hline Arabismo & Transcripción \\
\hline albahaca & al-ḥanbaq \\
\hline algodón & al-qutun \\
\hline azahar & azhār \\
\hline azucena & sausaneh \\
\hline jazmín & yāsamīn \\
\hline nenúfar & nāfūrah \\
\hline
\end{tabular}

Cuadro 14. Sustantivos de arbustos, plantas y flores

\begin{tabular}{|l|l|}
\hline Arabismo & Transcripción \\
\hline alcoba & alqūbah \\
\hline azotea & al-sațīhah \\
\hline azulejo & azzullāj \\
\hline baldosa & balāṭ \\
\hline tabique & tašbik \\
\hline zaguán & zagāo \\
\hline
\end{tabular}

Cuadro 15. Sustantivos de partes de la casa y piezas de construcción

\begin{tabular}{|l|l|}
\hline Arabismo & Transcripción \\
\hline alfiler & al-jallāl \\
\hline almirez & almidet \\
\hline candil & qandīl \\
\hline carrafa & jarrāfah \\
\hline jarra & jarah \\
\hline taza & tasah \\
\hline
\end{tabular}

Cuadro 16. Sustantivos de recipientes y utensilios domésticos

\begin{tabular}{|l|l|}
\hline Arabismo & Transcripción \\
\hline añil & al-n̄̄l \\
\hline ascarlata & sūqlāṭ \\
\hline
\end{tabular}

Cuadro 17. Sustantivos de nombres de colores 


\begin{tabular}{|l|l|}
\hline Arabismo & Transcripción \\
\hline albañil & albannā' \\
\hline alcalde & alqadī \\
\hline alamín & alamīn \\
\hline alhamel & 'āmil \\
\hline cadí & kadī \\
\hline alhamel & al-ḥammal \\
\hline alcaide & alqā’’id \\
\hline
\end{tabular}

Cuadro 18. Sustantivos de profesiones y cargos

\begin{tabular}{|l|l|}
\hline Arabismo & Transcripción \\
\hline alcázar & alqaser \\
\hline ámbar & 'andar \\
\hline jarabe & šaraāb \\
\hline máscara & masxarah \\
\hline nácara & nāqra \\
\hline
\end{tabular}

Cuadro 19. Otros sustantivos

El resultado de la distribución semántica de los sustantivos en los arabismos, de la cual se da una muestra en los cuadros anteriores porque es la más abundante respecto a las demás categorías gramaticales, deja información sociocultural importante relacionada directamente con un claro indicador de las áreas o aspectos en que los árabes influyeron en la Península Ibérica.

Además de los sustantivos ya mencionados, hay otra larga lista de sustantivos que son arabismos que se identifican porque comienzan por "al-" ya que toman la forma árabe con el artículo determinado original anexo, /al-/. Hay que aclarar al respecto para facilitar el aprendizaje que en la forma árabe original el sonido consonántico /l/ se omite duplicando la consonante posterior cuando se trata de consonante solar, en cuyo caso el arabismo comienza por $/ a /$ y no va seguido de $/ l /$, con lo que ya no se detecta el origen árabe de forma evidente. Se relacionan los siguientes (Alatorre, 2016):

- aceituna, del árabe hispánico /azzaytūn/ (procedente del árabe clásico /zaytūn/);

- adalid, del árabe hispánico /addalīl/ (procedente del árabe clásico /dalīl/);

- adive (chacal), del árabe hispánico /aḍdīib/ (procedente del árabe clásico /dīib/);

- ajedrez, del árabe hispánico /aššațranğ/ o /aššițranğ/ (procedente del árabe clásico /ash-shatranj/) que significa elefante montado;

- alacena, del árabe hispánico /alhazāna/ (procedente del árabe clásico /hizānah/);

- albacea, del árabe hispánico /(șāḥb) alwașīyya/;

- albahaca, del árabe hispánico /alḥabāqa/ (procedente del árabe clásico /habaqah/);

- albañil, del árabe hispánico /albannī/ (procedente del árabe clásico /bannā/)

- albufera, del árabe hispánico /albuḥāyra/ (procedente del árabe clásico /buhayrah/ diminutivo de /bahrr/ 'mar');

- albur (mújol), del árabe hispánico /albūri/ (procedente del árabe clásico /buri/ o /al-buri/) que significa pez que salta en el agua repentinamente y es capturado; 
- alcancía, del árabe hispánico /alkanzīyya/ (procedente del árabe clásico /kanz/ 'tesoro', y éste del pelvi /ganǰ/);

- alcanfor, del árabe hispánico /alkafūr/ (procedente del árabe clásico /kāfūr/);

- alcázar, del árabe hispánico /alqāṣr/ (procedente del árabe clásico /qāṣr/);

- alcalde, del árabe hispánico /alqāḍi/ (procedente del árabe clásico /qāẹ̄î,, ‘juez’);

- álgebra, del latín tardío /algĕbra/ (procedente del árabe clásico /alğabru/);

- alguacil, del árabe hispánico /alwazīr/ (procedente del árabe clásico /wazīr/);

- almádena, del árabe hispánico /almāțana/ (procedente del árabe clásico /mi‘dan/);

- almazara, del árabe hispánico /alma'șāra/ (procedente del árabe clásico /ma‘ṣarah/);

- almohada, del árabe hispánico/almuhnādda/ (procedente del árabe clásico/mihnaddah/):

- arroba, del árabe hispánico /arrūb\% (procedente del árabe clásico /rūb\%, 'cuarta parte');

- $\quad$ arroz, del árabe hispánico /arrāwz/ (procedente del árabe clásico /ruz[z]/);

- azafrán, del árabe hispánico /azza‘farān/ (procedente del árabe clásico /za‘farān/);

- azúcar, del árabe hispánico /assūkkar/ (procedente del árabe clásico /sukkar/, 'azúcar').

También es fundamental, para facilitar el aprendizaje de la segunda lengua, el conocimiento de otros sustantivos que son arabismos que empiezan por "guad-" del árabe clásico واد / واد $/ w d /$, referido a valle o río y que son nombres propios hispánicos, generalmente toponímicos (Alatorre, 2016) por ejemplo:

- Guadalajara, del árabe hispánico /wād alhayâara/, 'valle de Las Piedras';

- Guadalquivir, del árabe hispánico /wad alkabīr/, 'río grande';

- Guadalhorce, del árabe /wād aljurs/, 'río de los silenciosos';

- Guadalimar, del árabe /wād alahmar/, 'río rojo';

- Guadarrama, del árabe /wād arraml/, 'río del arenal';

- Guadiana, del árabe /wād/ y el latín ana ('pato'), 'río de patos'

Otros sustantivos muy usados en el habla común son los siguientes:

- cifra y cero, del árabe hispánico /șifr/ (procedente del árabe clásico /șifr/);

- guitarra, del árabe /qīinārah/;

- limón, del árabe hispánico /la[y]mún/ (procedente del árabe clásico /laymūn/);

- medina, del árabe hispánico /madīna/ (procedente del árabe clásico /madīnah/, 'ciudad');

- naranja, del árabe hispánico /naranğa/ (procedente del árabe clásico /nāranğ/);

- ojalá, del árabe hispánico /in šā' allāh/, 'si Dios quiere';

- tarea, del árabe hispánico /țarīḥa/ (procedente del árabe clásico /țarīḥa/, 'echar’);

- zanahoria, del árabe hispánico /safunnārya/

\subsubsection{Los adjetivos}

Es muy poca la cantidad de adjetivos identificados como arabismos, situación de la que no hay explicación pese a que hay una gran suma de sustantivos, como ya se mencionó, y a 
que el adjetivo es la palabra que acompaña al sustantivo para expresar una cualidad de la cosa designada por él o para determinar o limitar la extensión del mismo. Se destacan los siguientes (Vernet, 1960, p. 2) que son enérgicamente valorativos:

- baladí: de árabe /baladi/ significa 'nacional, de la tierra'. Tomó el sentido de 'poco importante';

- baldío: relacionado con 'de balde' y 'en balde' que son adverbios de origen árabe;

- rahez: del árabe /rajiz/, significó originalmente 'barato', y pasó a significar 'vil, despreciable';

- jarifo: 'de primera clase, noble', vino a significar 'vistoso, gallardo';

- horro: del árabe /hurr/, significaba 'de condición libre, no sujeto a obligaciones', un esclavo horro era el emancipado;

- mezquino: del árabe /mesquin/, 'indigente, desnudo, miserable'.

\subsubsection{Los artículos}

Con los artículos ocurrió algo particular en los arabismos: persistieron los elementos de origen árabe, de manera que muchas palabras que entraron en préstamo fueron incorporadas con el artículo definido /al/ que pasó a formar parte de los respectivos vocablos de origen arábigo sin su valor morfológico, de modo que todos ellos se volvieron a definir en español. En los arabismos incorporados con el artículo /al/ que comienzan con una de las consonantes lunares, $/ l /$ mantiene su valor fonético, sin embargo, en aquellos que comienzan con una de las consonantes solares, ésta aparece asimilada a la consonante inicial correspondiente, dando origen a una geminación que en el arabismo será simplificada, siempre que no se trate de /rr/ (Millar, 1998, p. 791). Así lo muestra el Cuadro 20.

\begin{tabular}{|l|l|}
\hline Arabismo & Transcripción \\
\hline albahaca & al-habqa \\
\hline alcurnia & al-kunya \\
\hline alcázar & al-qasr \\
\hline arroz & ar-ruzz \\
\hline aceite & az-zait \\
\hline azúcar & as-sukkar \\
\hline almacén & al-majzan \\
\hline arrayán & ar-rayhan \\
\hline
\end{tabular}

Cuadro 20. Los artículos en los arabismos en español

Hay que mencionar que el artículo /al/ aparece sobre todo en palabras incorporadas durante la primera época de la dominación árabe, siendo su vía de ingreso el habla popularoral, luego la mayoría de los vocablos no presentan artículo ya que ingresaron a través del habla culta como elementos del léxico independientes. Aunque gran parte de los arabismos presentes hoy en la lengua española comienzan con /al/ por la presencia del artículo, ese no es un rasgo distintivo únicamente de las palabras de origen árabe. 


\subsubsection{Los verbos}

Los verbos identificados como arabismos son muy pocos (Lapesa, 1984).

- recamar era 'tejer rayas en un paño' y se refería a un quehacer que era y sigue siendo muy especializado y es 'bordar con realce';

- acicalar era 'pulir';

- halagar era también 'pulir' y 'alisar'. El significado de ese verbo se trasladó a la esfera moral y se refiere a 'tratar a alguien con delicadeza, con cariño', exactamente significa 'alisarle el cabello', por lo que, por corrupción, se asume como 'adular, engatusar'; se agrega a esa lista un cuarto verbo, el arcaico margomar, sinónimo de recamar

Hay otros verbos usados en las jarchas como alfombrar, alambicar y ser. Este último ofrece formas diptongadas: tú yes, él yed.

- el verbo descender adquirió la acepción de 'alojar' que viene del verbo nazara: 'alojar, hospedar';

- los verbos correr y andar recogieron los matices de la voz árabe andando. El verbo correr se interpreta como 'hacer incursión';

- el verbo enfaronear, compuesto por en + farur + ar quiere decir 'volverse remiso, acobardarse';

- el verbo faronear quiere decir 'haraganear';

- el verbo maravillar quiere decir 'asombrarse';

- el verbo tornafuy es el equivalente a 'torna y huye', es decir, 'ataca y se retira' (Maillo Salgado, 1991);

- la cuarta forma (voz causativa) de los verbos árabes se caracteriza por anteponer un álif $(a)$ a la raíz trilítera cuya primera consonante toma posición implosiva: a la forma básica hazina, que significa 'estar triste', corresponde la cuarta ahzana que es 'entristecer, afligir'; a karuma que significa 'ser noble', akrama, que es 'honrar a otro'; a veces el álif es el único morfema causativo (māta: 'morir', amāta: 'matar').

\subsubsection{Los pronombres}

Se mencionan las siguientes formas de pronombre personal (Pérez Moreta y Viudas Camarasa, 1998, pp. 327 y ss.):

- $\quad$ primera persona: eo;

- $\quad$ segunda persona: tú (plural vos);

- $\quad$ tercera persona: ellu, él;

- En el caso de régimen aparecen: primera persona: mib, mibi; segunda persona: tib, tibe y las formas átonas me, te, os, se.

- También proceden del árabe los pronombres indefinidos fulano y mengano.

\subsubsection{Las preposiciones}

Entre los arabismos identificados en español se encontraron dos preposiciones básicas (Mikinasi, 1963) y otras que en los arabismos funcionan con una estructura gramatical de 
adaptación a las interjecciones con las que van unidas, por eso se encuentran las expresiones "de balde" o "en balde", palabra esta última del mismo origen que baldio, "he aquî", "he allî", “desde... hasta...". Las básicas son:

- hasta: /atal

- he: utilizada para preguntar

Las otras son:

- de, he, desde, en.

\subsubsection{Las interjecciones}

El español cuenta con un único caso de locución en que un giro idiomático procedente del árabe se ha configurado en una interjección sobradamente conocida: ojalá. Esta palabra procede de la expresión condicional hipotética árabe traducida como en quiera Dios /Law šăAllah/ formada por tres palabras en esta lengua. La solución romance evolucionó hasta convertirse en una sola palabra con el consiguiente cambio de categoría gramatical produciéndose así un fenómeno de castellanización del nombre (Maíllo Salgado, 1991, p. 477). La mencionada partícula expresa deseo de realización posible o hipotética, por lo que según el matiz o valor que el hablante transfiera a su discurso, ojalá permite verbos conjugados en presente, pretérito perfecto, imperfecto o subjuntivo. Por otra parte, su empleo aislado como expresión de una situación determinada o de un estado de ánimo concreto, tiene en español un uso mucho más restringido que en árabe, por no decir nulo, dado que en esta lengua dicha locución no sólo introduce la oración condicional hipotética, sino que al mismo tiempo posee un marcado valor auto semántico: “ique Dios quiera!”, y en sentido irónico “ique Dios te oiga!”. Otra interjección muy común es jya!, usada múltiples veces en El Cantar del Mío Cid y que en ese contexto se traduce como ‘¡oh!', pero que en el habla común española se utiliza como 'ahora, en este instante'.

\subsubsection{La morfología}

La única fuente para extraer rasgos morfológicos sobre el dialecto mozárabe son las jarchas (de Urioste, 2001). Algunos aspectos morfológicos de los arabismos en ellas son:

- $\quad$ aparecen mib y mibi como formas analógicas de mí;

- como artículo indefinido, se documenta otri;

- $\quad$ se conserva la - $t$ desinencial convertida en - $d$ : tornarád, sanarád;

- la negación mantiene su - $n$ final: non; y la preposición ad se utiliza sin pérdida de la $-d$;

- la copulativa tiene la forma $e d$;

- $\quad$ se conserva el participio con la -t- latina: wastato, tornato;

- alternancia de las formas de futuro en ei: kery; en -ayo, -ayu: farayo, vivrayu;

- el cambio de -as en - $s$ en algunos plurales: cabanes, magranes o granadas;

- formas meu y ma para el adjetivo posesivo: meu cidello, ma alma;

- los interrogativos qui, que y los indefinidos otri, otris;

- $\quad$ el infinitivo ofrece la - $e$ final: volare, matare. 


\subsubsection{La fonética}

Ofrece la fonética una opción interesante para el aprendizaje de la segunda lengua y contribuye a dilucidar la fisiología de los sonidos árabes y su evolución al incorporarse al léxico románico (Steiger, 1932). Véase Cuadro 21.

\begin{tabular}{|l|l|}
\hline Arabismo & Transcripción \\
\hline algarabía & al'arabiyyah \\
\hline aljamía & al'jamiyya \\
\hline casida & qașīdah \\
\hline ojala & enša' Allah \\
\hline cúfico & kūfī \\
\hline
\end{tabular}

Cuadro 21. Comparación de la fisiología de los sonidos

En materia de pronunciación hay que decir que a pesar de los arabismos, la huella del árabe es escasa. A fines del siglo XV se creía que tres sonidos del español, la $/ h /$ de herir, -/herir/-; la /x/ de deshar, -/dexar/-; y la /ts/ de fuerça, -lfuertsa/-; inexistentes en latín, eran herencia de los árabes (Nebrija, 2016). En la actualidad todavía se oye decir que la $<j>$ española de "ajo" y de "juerga", inexistente en francés y en italiano, tiene como procedencia el árabe. Casi todos los arabismos se pronuncian con fonética hispánica.

No menos interesantes son los arabismos semánticos que no pasaron al español con su materia lingüística, sino con su espíritu. Ellos revelan una comunión íntima entre las dos lenguas. Palabras tan españolas y de etimología tan latina como fijo de algo: "hidalgo" y como infante/infanta: "hijos del rey", son arabismos semánticos. Así mismo la costumbre de decir "si Dios quiere", o "que Dios te ampare", o "don Alonso a quien Dios guarde", o "bendita la madre que te parió", es herencia de los árabes.

\section{Los topónimos}

Uno de los aspectos que más facilita el aprendizaje del español y del árabe como segunda lengua, por ser de las mayores presencias de los arabismos en el español, se da a nivel de la toponimia que se refiere al dominio árabe de filiación lingüística en la Península Ibérica. Sobre el tema hay muchos estudios (Llorente Maldonado de Guevara, 1991, p. 12). Véase Cuadro 22.

\begin{tabular}{|l|l|l|}
\hline Arabismo & Significado en español & Transcripción \\
\hline albacete & el llano & al-basīt \\
\hline alcántara & el pasadizo, el puente & al-qanțarah \\
\hline almería & el espejo & al-mīrah \\
\hline algeciras & la isla, verde & al-ŷazirah al-jaḍrā' \\
\hline guadalquivir & el valle grande & al-wadī al-kabīr \\
\hline medina & la ciudad & madīnah \\
\hline
\end{tabular}

Cuadro 22. Algunos topónimos entre los arabismos en español 
Junto a los topónimos están los gentilicios de origen árabe, cuya derivación repercute en el sistema morfológico y fonético del romance adaptándose generalmente a éste como adjetivos en /í/; no obstante, estos derivados a menudo generan su correspondiente sinónimo equivalente, en virtud de un sufijo romance, dando lugar a dobletes como: ceutí, magrebí, marroquí. La enumeración consecutiva de estas parejas sinonímicas de gentilicios indica que la mayor parte de este tipo de arabismos fue adoptada por el sistema romance, cayendo en desuso en algunos casos la correspondiente derivación española (Walsh, 1971, p. 163).

Otros topónimos, son los siguientes (Hidalgo Paniagua, 2007):

- Andalucía: la más poblada y meridional de las comunidades autónomas españolas. Es el nombre árabe de la Península Ibérica bajo el dominio musulmán;

- Albacete: ciudad y provincia de la región de Castilla, La Mancha. Su nombre proviene del árabe al basit, 'la planicie, la llanura';

- Alcalá: varios municipios tienen este mismo nombre. Por ejemplo Alcalá de Guadaíra, Alcalá de los Gazules, Alcalá del río o Alcalá de Henares. También otras localidades probablemente como Santa Olalla del Cala (Huelva). Del árabe al-qalaia, 'el castillo';

- Algeciras: ciudad y puerto de la provincia de Cádiz, Andalucía. Deriva de al jazeera al khadra, 'la isla verde';

- Almería: ciudad de la región autónoma de Andalucía. Deriva de al meraya, 'atalaya, torre de observación';

- Alpujarras (originalmente Alpuxarras): región que se extiende desde Granada en el sur hasta Almería. Del árabe al-busherat, 'tierras de pastoreo';

- Gibraltar: Peñón de Gibraltar, montaña de la cordillera Penibética, deriva de la palabra árabe yabal tāriq que significa 'montaña de Tariq', en recuerdo del general musulmán Táriq ibn ziyad;

- Guadalajara: ciudad y provincia de la región de Castilla-La Mancha. Deriva de wād̄ al-hijārah, 'río o cañón de piedras';

- Guadalquivir (Río): deriva del árabe al-wādĩ al-kabir, 'el gran río’;

- Guadalupe: municipio situado en la provincia española de Cáceres. Su etimología es un híbrido entre el árabe $w \bar{a} d \bar{\imath}$ y el latín (lupus, lupi), y significa 'río de los lobos';

- Henares: deriva del árabe an-nahar 'el río';

- Jaén: ciudad de Andalucía, viene del árabe jayyan, 'encrucijada de caravanas';

- La Mancha: nombre histórico de las amplias estepas áridas que abarcan gran parte de las provincias de Albacete, Ciudad Real, Cuenca y Toledo. Su denominación deriva del árabe la'a ma-anx, que literalmente significa 'sin agua';

- Medina Sidonia: pueblo y municipalidad en la provincia de Cádiz Deriva del árabe madīnah, 'ciudad';

- Tarifa: pueblo del sur de España. Originalmente jazira tarif 'la isla de Tarif'. Proviene del primer nombre del conquistador Tarif ibn malik;

- Trafalgar: del árabe andaluz taraf-al-ghar, que literalmente significa 'estrecho'

- Murcia: del árabe mursiyah, 'embarcadero';

- Zújar: del árabe sujair, 'rocas'. Pueblo de la comarca de Baza, en la provincia de Granada; 
- La Malahá: del árabe al maliha, 'la salina', por las salinas ubicadas en ese pueblo granadino;

- La Almarcha: del árabe al merya, 'el prado, el humedal'.

Estos topónimos de origen hispanoárabe se dividen en tres grupos. El primero comprende nombres que no son estrictamente topónimos de dicho origen, sino arabismos utilizados ocasionalmente en la toponimia, sin que ello suponga absorción por las lenguas hispánicas de toponimia originariamente hispanoárabe: diversas acequias lassáqyal o /al-sāqiyah/, alcalás /al-qal“-at/, aldeas /al-dayäs/, aljibes /alğúbb/ o /algúbb/, alcázares /al qaçr/, arrabales /rabad/, atalayas /țalā'il, azudas /assúdd/, dulas /dawlah/, mezquitas /masgid/, norias /naürah/, ráfales /aáafat/, rábitas /ribāțT/, ramblas /ramlah/ y tahonas /ațtạhūn/ (Gea, 2003). Véase Cuadro 23.

\begin{tabular}{|l|l|}
\hline Arabismo & Transcripción \\
\hline acequias & al-pujarra, al-bardana, al-baida, al-fateago, al-juña, al-jaledo \\
\hline alcalá & calatayud, alcalaíno, complutense, al-qal'a Nahar \\
\hline aldeas & al-capela, al-barry, al-arán, al-lama \\
\hline aljibes & al-merias, al-baicin \\
\hline alcázar & al-cassaro, alázar de Toledo \\
\hline atalayas & barrianas, casar \\
\hline noria & al-barracin \\
\hline
\end{tabular}

Cuadro 23. Topónimos de uso ocasional

Al segundo grupo pertenecen topónimos descriptivos. Véase cuadro 24.

\begin{tabular}{|l|l|}
\hline Arabismo & Transcripción \\
\hline zaragoza & $\begin{array}{l}\text { alborge /alburj/ 'la torre', la albotea /al-butáyha/ 'el llanillo' } \\
\text { alhama /al-hamma/ 'la fuente termal } \\
\text { almazán /al-mahsán/ 'la guarnición' y almozara /al-musára/ } \\
\text { 'el paseo' }\end{array}$ \\
\hline huesca & $\begin{array}{l}\text { albelda al-bálda 'el pueblo', } \\
\text { alcabón /al-qabú/ 'la chimenea', } \\
\text { alcolea /al-qulay'a/ 'el castillejo' }\end{array}$ \\
\hline teruel & $\begin{array}{l}\text { /ad-daymús/ 'el escondrijo', } \\
\text { almohaja /al-muhájja/ 'el camino', } \\
\text { zoma /súm'a 'alminar'/ } \\
\text { zueca /suwáyqa/ 'mercadillo' ademuz }\end{array}$ \\
\hline
\end{tabular}

Cuadro 24. Topónimos descriptivos

Finalmente, en el tercer grupo están los topónimos que incluyen antropónimos referidos a aquellos que identifican a las personas que dieron nombre a un lugar en determinadas circunstancias. Véase Cuadro 25.

\begin{tabular}{|l|l|}
\hline Arabismo & Transcripción \\
\hline el escondrijo & ad-daymús \\
\hline el camino & almohaja /al-muhájja/ matá'al-'As/ \\
\hline
\end{tabular}




\begin{tabular}{|l|l|}
\hline mercadillo & ademuz \\
\hline propiedad de musa & peña del matalaz /matamuza/ matá'músa \\
\hline
\end{tabular}

Cuadro 25. Antropónimos o palabras que identifican a personas que dieron nombre a un lugar

\section{Otros campos de influencia de los arabismos}

Otra fuente de información que facilita el aprendizaje de la segunda lengua la conforman otros campos de influencia de los arabismos. Los árabes estuvieron más tiempo en algunas zonas de España que en otras, por ese motivo su influencia fue importante en la agricultura. Su jardinería fue de gran perfección artística (Lapesa, 1984, p. 38). Al crear nuevas técnicas de aprovechamiento del agua desarrollaron la agricultura de regadío, que favoreció la introducción o desarrollo de cultivos de frutales y hortalizas que necesitaban agua.

Las novedades en los trabajos y productos agrícolas se reflejaron en novedades léxicas que el castellano fue adoptando. Así se encontraron nombres arábigos de árboles como almez, acebuche, alerce, naranjo, alcornoque, algarrobo, acebuche; nombres sobre la organización del terreno agrícola como bancal, baldío, y acirate; arabismos sobre el aprovechamiento del agua como arcadus, ador, noria, azud, alberca, aljibe, acequia, alema, ador, acirates, jaricar; arabismos sobre frutos como lima, naranja, aceitunas, albaricoques, limones, azufaifas, algarrobas y bellotas; hortalizas como alubia, alcachofa, berenjena, espinaca, acelga, zanahoria, alcaravea; condimentos como azafrán y ajonjolí y arabismos de jardinería como arriate, adelfa y ajenuz (Esopo, 2009).

En materia de arquitectura, arte y construcción los arabismos se posicionaron en el mundo castellano. Los hay de habilidades manuales, elementos artesanales, constructivos con un lenguaje propio dentro de la arquitectura. El léxico se extendía a maestros de obra, a partes de las viviendas, por ejemplo: acicalar, /siqúl/, 'instrumento para pulir o bruñir'; adobe, lattúb/ o /ladrillo/, 'masa de barro a veces mezclado con paja en forma de paralelípedo' o 'cubo de seis caras paralelas de dos a dos, secado al aire que se emplea en la construcción de muros'; adoquín, laddukkán/ o laddukkín/, 'piedra labrada en forma de prisma rectangular para empedrados y otros usos'; albañal, /alballá 'al, 'canal o conducto que da salida a las aguas negras'; albañil, /albanní/, 'maestro en el arte de construir edificios con ladrillos, piedras u otros materiales' o 'conocedor de oficios como murador (que sube o escala muros), tapiador, mazonero, pedrero, oficial y maestro de obra'; zaguán, /istawán/, 'portal o entrada de la casa'. (Guerra Obando, 2002, p. 38).

En materia de milicia también se han identificado arabismos. Véase cuadro 26 que muestra los trece campos o subgrupos donde dominaron los arabismos en España. El primero de ellos, denominado varios, agrupa una serie de vocablos que no tienen cabida en los restantes subgrupos, y no forman por sí mismos un campo semántico. Los otros, en orden a la cantidad de arabismos identificados, son de mayor a menor: vestidos, fauna, milicia, navegación, mineralogía, ocio, arquitectura, alimentación, comercio, cargos, música y colores.

\begin{tabular}{|l|l|}
\hline alférez & $\begin{array}{l}\text { /fares/ 'el caballero' o 'el jinete', se refiere a un grado inferior de la oficialidad } \\
\text { militar en varias fuerzas armadas. }\end{array}$ \\
\hline arsenal & $\begin{array}{l}\text { /dārașșinā'ah/ que significa 'taller', aunque en la actualidad se refiere a un } \\
\text { depósito de armas, munición y otros pertrechos militares. }\end{array}$ \\
\hline
\end{tabular}




\begin{tabular}{|l|l|}
\hline asesino & $\begin{array}{l}\text { /haššāšĩn/, se utilizaba para referirse a los 'adictos al cáñamo indio'. Ahora } \\
\text { se refiere a una persona ofensiva, hostil o dañina que mata a alguien con } \\
\text { premeditación o alevosía. }\end{array}$ \\
\hline cid & $\begin{array}{l}\text { /síd/ apodo de Rodrigo Díaz de Vivar que significa 'hombre fuerte y muy } \\
\text { valeroso'. }\end{array}$ \\
\hline mameluco & 'esclavo'. \\
\hline almohade & $\begin{array}{l}\text { /muwahidun/ Dinastía marroquí de origen bereber que dominó el norte de África } \\
\text { y el sur de la Península Ibérica del año } 1147 \text { al 1269. Hoy el término se refiere a } \\
\text { los que solo reconocen la unidad de Dios. }\end{array}$ \\
\hline almogávar & $\begin{array}{l}\text { /al-mugāwir/ grupos armados de sarracenos que se dedicaban al saqueo y los } \\
\text { ataques sorpresa. }\end{array}$ \\
\hline
\end{tabular}

\section{Cuadro 26. Arabismos en el campo militar}

El Cuadro 27 y la Figura 1 dan una visión de los subgrupos de arabismos (Maillo Salgado 1991, p. 231) así:

1. Varios: fasta, achacar, arrebatar, fulano.

2. Arquitectura y urbanismo: acequia, adobe, alberca, tahonas.

3. Vestido y ornamentos: abolorios, ajorca, albornoz, alpargatas.

4. Alimentos y culinária: aceite, albarcoques, alcorza, algarrobas.

5. Relativo a animales: alazán, alcandra, alcatraces, alcotanes.

6. Comercio y propiedades: alcabala, almojarifazgo, alquilar, arroba.

7. Milicia: adarga, alfanje, algarada, cerbatana.

8. Nombramientos y cargos: albacea, alcaide, alférez, alguacil.

9. Navegación: arrejaques, calafate, falca, gálibo, maroma.

10. Música: atabal, atambor, zambra.

11. Mineralogía: al ( h)inde, alquitrán, azabache, rejalgar.

12. Colores: alheñada, almagra, azul, zaino.

13. Ocio: ajedrez, alquerque.

\begin{tabular}{|l|c|}
\hline \multicolumn{2}{|c|}{ Arabismos en el español } \\
\hline Arabismos & Frecuencia en \% \\
\hline varios & 17 \\
\hline vestidos & 2 \\
\hline fauna & 3 \\
\hline milicia & 4 \\
\hline navegación & 4 \\
\hline mineralogía & 5 \\
\hline ocio & 6 \\
\hline arquitectura & 6 \\
\hline alimentación & 6 \\
\hline
\end{tabular}




\begin{tabular}{|l|c|}
\hline comercio & 8 \\
\hline cargos & 12 \\
\hline música & 13 \\
\hline colores & 14 \\
\hline \multicolumn{1}{|c|}{ TOTAL } & 100 \\
\hline
\end{tabular}

Cuadro 27. Subgrupos temáticos de arabismos

\section{Arabismos}

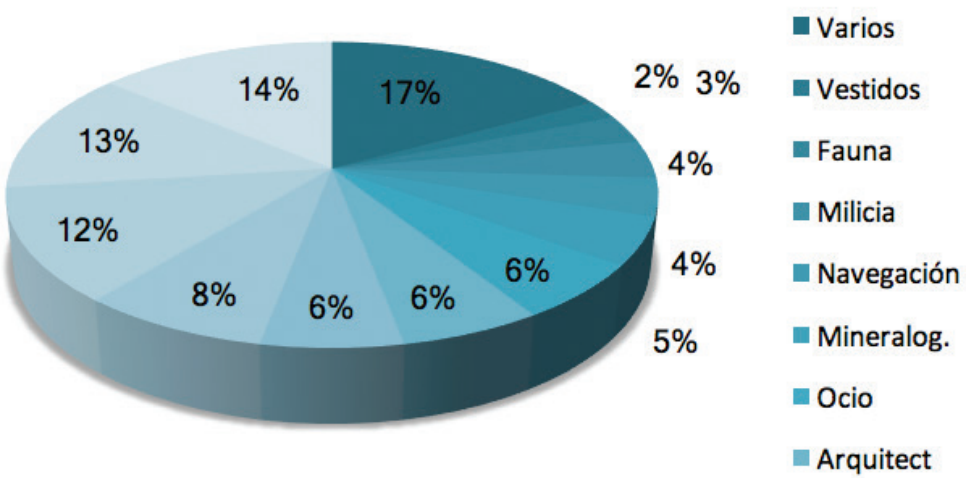

Figura 1. Proporción porcentual de subgrupos temáticos de arabismos en español

A los datos anteriores se suman una relación de arabismos surgidos en los diferentes ciclos o períodos de tiempo reportados. Tal como se muestran en los Cuadros 28 a 30.

\begin{tabular}{|l|l|l|l|}
\hline abarraz & alfajor & atutia & jabalí \\
\hline acebuche & alfareque & ramia & jáquima \\
\hline aceche & alfarda & azarón & jinete \\
\hline aceituna & alfarida & azarote & laúd \\
\hline acíbar & alfeñique & azemín o jazmin & limón \\
\hline alacena & aljamía & barbacana & naranja \\
\hline alarguez & almizcle & cande & quina \\
\hline albarioque & almori & cifaqui & teliarmin \\
\hline albornoz & altabaque & codra & toronja \\
\hline albur & altramuz & culame & zaguia \\
\hline alcandora & arracada & elche & zahara \\
\hline aldaba & atún & halia & \\
\hline
\end{tabular}

Cuadro 28. Voces del primer período: 1300-1305 


\begin{tabular}{|l|l|l|l|}
\hline acemite & alcachofa & alcurnia & alhaite \\
\hline ación & alcamonías & aledan & alhanía \\
\hline ajorca & alcanería & alficoz & alina \\
\hline alafa & alcanfor & alfombra & alizar \\
\hline alambique & alcaravea & alfobrilla & ajonjolí \\
\hline alamud & alcatifa & alforja & almadraba \\
\hline albacete & alcazaba & algarbe & almea \\
\hline albahaca & alcorci & algazafan & almez \\
\hline albóndica & alcrebite & algebrista & almirez \\
\hline alcabaz & alcufa & alguaquida & almorajub \\
\hline aloque & badea & zunca & orozuz \\
\hline alquitira & berenjena & hacino & sandía \\
\hline arrope & cacís & jaez & tamarindo \\
\hline azabache & ciclán & mamarracho & tunecí \\
\hline azotea & galibo & mojama & zarzajan \\
\hline azulejo & garaca & nicar & \\
\hline azúmbar & gorguz & ojalá & \\
\hline
\end{tabular}

Cuadro 29. Voces árabes del segundo período: 1350-1454

\begin{tabular}{|l|l|l|l|}
\hline acicate & almaizar & cifra & muley \\
\hline adrada & almalafa & gandul & romia \\
\hline alacer & almarada & gerba & taha \\
\hline alarife & almazara & habiz & tahalí \\
\hline albaquía & almojábana & halda & tarea \\
\hline albarrada & alquilate & jamila & taybo \\
\hline alcorza & alubia & jaracuna & tomín \\
\hline aldrán & anta & majarón & zagal \\
\hline alejija & añafea & mameluco & zajén \\
\hline
\end{tabular}

Cuadro 30. Voces árabes del tercer período. 1454-1514

Los cuadros anteriores, confirman, como ya se ha dicho, que las palabras de origen árabe figuraban, y siguen figurando, de forma habitual en el habla cotidiana del pueblo español, por lo tanto, resulta bastante lógico el hecho de que estos términos pasaran al actual mundo hispano. Tener una idea de la historia y de esos arabismos desde los diferentes campos, amplia el horizonte del vocabulario de los aprendices y sirve como punto de contacto entre las dos lenguas.

\section{Etapas de los arabismos en España}

La relación lingüística entre el árabe y el español marcó períodos que tuvieron que ver directamente con las etapas de la dominación árabe y comprendió la expansión y el retroceso de los arabismos. Véanse las Figuras 2, 3, y 4 (Millar C, Salgado Núñez y Zedán Lolas, 2005, p. 783). 


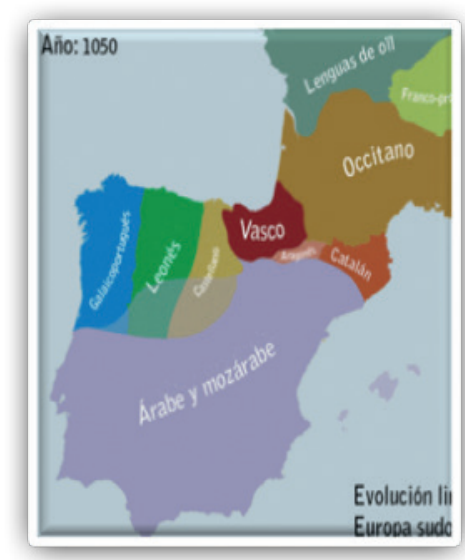

Figura 2. Los árabes en España, año 1050

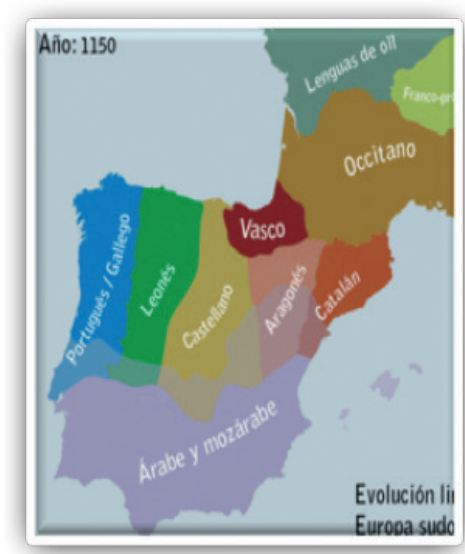

Figura 3. Los árabes en España, año 1150

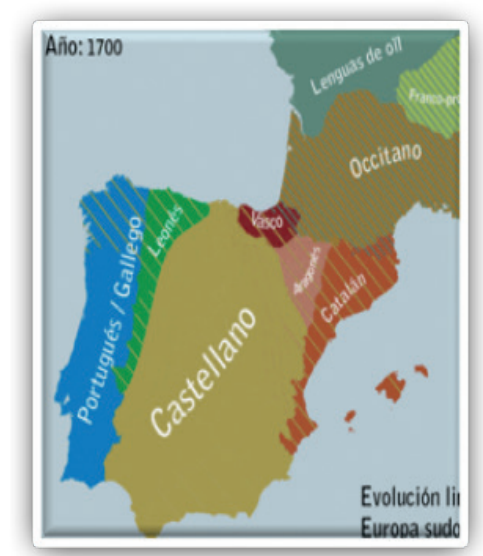

Figura 4. Los árabes en España, año 1170 
Al llegar los musulmanes se impuso su lengua árabe, pero en los pueblos y algunas ciudades los habitantes siguieron usando la lengua propia, así coexistieron cuatro variedades lingüísticas: el árabe clásico para documentos oficiales, literarios y científicos; el árabe vulgar, o dialecto andaluz del árabe, como lengua conversacional; el latín, idioma litúrgico de los cristianos mozárabes, grupo que mantuvo su religión bajo la influencia musulmana, con escasa literatura (Lapesa, 1984) y por último, el romance o latín vulgar, usado como lengua familiar por los cristianos mozárabes, los españoles y aun por los mismos nobles árabes.

El uso de los arabismos ha variado según las épocas. Durante el Califato, cuando el centro del poder estaba en Córdoba, se introdujeron sin obstáculos ni competencia, sin embargo, durante la Baja Edad Media se retiraron frente a los latinismos, voces patrimoniales y extranjerismos. Un ejemplo de esta situación es que Villalobos (1515), citado por Lapesa (1984, p. 150), recriminaba a los toledanos porque "al usar arabismos afean y ofuscan la pulidez y claridad de la lengua castellana".

Los moriscos estuvieron en España con sus usos y costumbres, pero tras su expulsión en 1609, y con el avance de la conquista, los usos lingüísticos de muchos términos árabes fueron desechados y sustituidos por formas romances.

Otros se mantuvieron en el habla regional, pero la gran cantidad de ellos que subsiste con plena vida, muchos de ellos fundamentales, caracterizan el léxico hispano-portugués frente a los demás romances (Villalobos, 1515, p. 156).

\section{El estudio de los arabismos como estrategia de aprendizaje de la segunda lengua}

La experiencia docente permite afirmar que los alumnos asimilan con mayor competencia el aspecto semántico de los arabismos cuando este se explica remitiendo al significado árabe original que en muchos casos se conserva en el español. En los casos en que se han producido cambios de significado en la adaptación de un arabismo al sistema romance, debe ayudarse a los alumnos para que puedan asimilar con menor dificultad el nuevo arabismo.

Está probado que el conocimiento de estos dos fenómenos lingüísticos, la relación de identidad entre los significados árabe y español y el cambio de significado, influyen en la interrelación existente entre las cuatro destrezas comunicativas (expresión oral, expresión escrita, comprensión auditiva y comprensión lectora), que activan el uso de la lengua, pues éste será más efectivo cuanto más precisa sea la forma en que los alumnos conciben los arabismos. Por otra parte, la existencia de un sinónimo romance frente a un arabismo, facilita la integración de ambos términos de palabras aprendidas; así, mientras más se ejercite esta habilidad, mayor será la competencia sociolingüística.

Es importante tener en cuenta que el mayor o menor rendimiento en la adquisición de arabismos como parte del vocabulario, está en relación directa con el nivel de contexto sociocultural inherente a cada hablante. Así pues, si se tiene en cuenta el valioso y significativo porcentaje de términos de origen árabe que existen en el español, los cuales responden a una base etimológica, la enseñanza del vocabulario no se relega solo a la enumeración sistemática de unos significantes y sus correspondientes significados en función del origen etimológico de cada vocablo, sino que dicha enseñanza lleva implícita además la transmisión de una cultura y de un modo de vida que se insertan en un marco diacrónico preexistente. 
Es además de gran valor que el alumno tome conciencia de que a lo largo de la historia la lengua española incrementó su léxico a través de la toma y el uso por parte de los hablantes de palabras de muchas otras lenguas, entre ellas el árabe. Así se promueve el reconocimiento del mestizaje lingüístico en la lengua española y a la vez se fomenta el conocimiento de los préstamos léxicos del árabe.

Después de que el alumno haya identificado un importante número de palabras árabes en la lengua española, el siguiente paso en su aprendizaje de la segunda lengua es el reconocimiento de las características ortográficas de los arabismos usados con mayor frecuencia, por ejemplo los que comienzan por la sílaba /al/ de los cuales este artículo incluye un buen número.

Por lo anterior, sería ocioso decir que los arabismos son solamente la manifestación de un tipo concreto de léxico, ya que son también la prueba fehaciente de un encuentro entre dos culturas. La ineludible simbiosis de estos dos niveles -el plano léxico-semántico por una parte y el socio-cultural por otra- deben ponerse de relieve de forma sistemática tanto en la clase de español como en la de árabe, sistemas con grandes diferencias fonéticas que exigen, para reproducirlos, un proceso de acomodación linguíística en el que influye la falta de vocales en la ortografía del árabe y el uso de hiatos y diptongos porque éstas con frecuencia no se reproducen gráficamente, porque son reducidas: $/ a /, / i /, / u /$.

Para finalizar conviene recalcar que el estudio de los arabismos en la clase de árabe y de español, no sólo contribuye favorablemente al aprendizaje de un subconjunto del vocabulario desde una perspectiva interdisciplinar, sino que además facilita el acercamiento a una cultura híbrida que en muchos aspectos asimiló usos, tradiciones y costumbres legadas por el complejo árabe.

\section{Conclusiones}

No queda duda del importante aporte pedagógico de los arabismos en el español para el aprendizaje de cualquiera de los dos idiomas como segunda lengua. Más que un recorrido memorizado por un extenso vocabulario, es la actitud de quien enseña, pero sobre todo del alumno, abierta al conocimiento de la historia común de los dos países, de los encuentros y desencuentros, del contexto social, geográfico y cultural, lo que animan a facilitar la disposición para hacer los ajustes de pronunciación y significación que propone el artículo.

Mucho se ha dicho sobre el tema de los arabismos en el español, pero han sido menores los aportes sobre el abordaje pedagógico para aprender una segunda lengua. Morfología, sintaxis y semántica, aspectos gramaticales sumados al léxico, forman parte de la estrategia que contribuye a valorar el legado y a hacer viable la invitación a aprender dos idiomas llenos de nexos comunes. Si se es consciente del impacto etimológico que el árabe tiene en el español y de la riqueza de aprender una u otra como segunda lengua rompiendo barreras idiomáticas que la historia ha demostrado que no son grandes ni profundas. 


\section{Bibliografía}

Abad, F. (1986). Diccionario de lingüística de la escuela española. Madrid: Gredos.

Alatorre, A. (2003). Los 1001 años de la lengua española. (3ªdición). Madrid: Editorial Fondo de Cultura Económica de España.

Alatorre, A. (2016). Los arabismos del español II. Recuperado de: http://algarabia.com/ lenguaje/los-arabismos-del-espanol-ii/

Aldrete, B. (1873). Vocablos arábigos que hay en el Romance. En G. Mayans y Sisear (Ed.). Orígenes de la Lengua Española. (2 ${ }^{\mathrm{a}}$. edición) (pp. 185-193). Madrid: Rivadeneyra.

Álvarez de Miranda, P. (1995). Hacia una historia de los diccionarios españoles en la Edad Media. Bulletin Hispanique, 97 (1), 87-200.

Ammadi, M. (2010). Historia y evolución de los arabismos en los diccionarios de la Real Academia Española. Universidad Hassan II: Casablanca.

Ariza, M. (2004). El romance en Al-Ándalus. En R. Cano (Coord.). Historia de la lengua española. Barcelona: Ariel.

Asín Palacios, M. (1940). Contribución a la toponimia árabe en España. Madrid: Imprenta Estanislao Maestre.

Borrego, J.; Gómez-Asencio, J. y Prieto, E. (1989). El subjuntivo: valores y usos. (3 ${ }^{\text {a }}$ edición) Madrid: SGEL.

Corriente, F. (1991). Árabe andalusí y lenguas romances. Madrid: MAPFRE.

Corriente, F. (1996). Hacia una revisión de los arabismos y otras voces con étimos del romance andalusí o lenguas medio-orientales en el Diccionario de la Real Academia Española. Boletín de la Real Academia Española, tomo 76, cuaderno 269, 371-416.

Corriente, F. (1997). Diccionario árabe-español. (3era. edición). Barcelona: Editorial Herder

Cruz Hernández, M. (1992). El Islam de Al-Ándalus (historia y estructura de su realidad social). Madrid: Agencia Española de Cooperación Internacional, I.C.M.A.

De Nebrija, A. (2016). Gramática de la lengua castellana. Madrid: Red ediciones.

De Palencia, A. (1999). Universal vocabulario en latín y en romance. (Edición facsímil de 1967.) Madrid: Biblioteca Nacional.

De Urioste, C. (2001). SPA 540 History of the Spanish Language Spring 2001. Recuperado de http://w3.salemstate.edu/ jaske/courses/readings/History_of_the_Spanish_Language_ Handouts_By_Carmen_de_Urioste.html

Dozy, R. (1881). Supplément aux dictionnaires árabes (2 vols). Leyde: E. J. Brill.

Dozy, R. y Engelmann, W. (1869). Glossaire des mots espagnols et portugais derivesde I 'Arabe. Leyde: E. J. Brill.

Dubois, J. et al. (1979). Diccionario de lingüística. Madrid: Alianza Diccionarios.

Eguílaz y Yanguas, L. (1886). Glosario etimológico de palabras españolas (castellanas, catalanas, gallegas, mallorquínas, portuguesas, valencianas y vascongadas) de origen oriental (árabe, hebreo, malayo, persa y turco). Granada: Ediciones La Lealtad. 
Esopo. (2009). Arabismos en el español de la agricultura y la jardinería. Recuperado de http:// www.blogolengua.com/2009/06/arabismos-agricultura-jardineria.html

Fernández López, J. (s.f.). Ceceo y seseo, origen y evolución histórica. Recuperado de: http:// hispanoteca.eu/gram\%C3\%A1ticas/Gram\%C3\%A1tica\%20espa\%C3\%B1ola/CeceoSeseo.htm

Fernández Ordóñez, I. (2011) Las lenguas del rey: de latín a las lenguas vernáculas en las cancillerías regias de la Península Ibérica. En Pascual Martínez Sopena \& Ana Rodríguez López (Eds.). La construcción medieval de la memoria regia. (pp. 323-361). Valencia: Universidad de Valencia.

Fernández Ramírez, S. (1986). La derivación nominal. Madrid: Real Academia Española.

Galisson, R. y Coste, D. (1976). Dictionnaire de didactique des langues. Paris: Hachette.

Galisson, R. (1979). Lexicología y enseñanza de la lengua. París: CLE International, Estudios de lingüística aplicada.

Galmes de Fuentes, A. (1958). Influencias sintácticas y estilísticas del árabe en la prosa medieval castellana. Bulletin Hispanique, 60 (4), 549-551.

García de la Concha, V. (2014). La Real Academia Española. Vida e historia. (1ª edición). Madrid: Espasa-Calpe.

García González, J. (1993). El contacto de dos lenguas: los arabismos en el español medieval y en la obra alfonsí. Cahiers de linguistique hispanique médiévale. (18-19), 335-365.

García Santos, J. F. (1993). Sintaxis del español, nivel de perfeccionamiento. Madrid: Santillana-Universidad de Salamanca.

GEA, Gran enciclopedia aragonesa. (2003). Toponimia hispanoárabe. Recuperado de: http:// www.enciclopedia-aragonesa.com/voz.asp?voz_id=20322

Giol y Soldevilla, A. (1983). Palabras españolas de origen árabe. Madrid: Darek Nyumba.

Glick, T. (1991). Cristianos y musulmanes en la Edad Media (711-1250). Madrid: Alianza Editorial.

González López, S. (2015). Más de 4000 palabras en castellano tienen origen árabe. Recuperado de: https://20000lenguas.com/2015/01/11/mas-de-4000-palabras-encastellano-tienen-origen-arabe/

Grossman, M. (1969). La adopción de los fonemas árabes al sistema fonológico del romance. Revue roumaine de linguistique, 14, (1), 51-64

Guerra Obando, B. (2002). Arabismos en la restauración del patrimonio arquitectónico. Bogotá: Pontificia Universidad Javeriana.

Harlan, C. (2014). Moaxaja. ABOUTESPAÑOL. Recuperado de https://www.aboutespanol. com/moaxaja-2206638

Harley, B., Cummins, J., Swain, M. y Allen, P. (1990). The nature of language proficiency. En B. Harley, J. Cummins, M. Swain y P. Allen. (Eds.). The Development of Second Language Proficiency. (pp. 7-25). Cambridge: Cambridge University Press. 
Hidalgo Panigua, D. (2007). Palabrario andaluz: Voces y expresiones del habla popular de Andalucía. España, Andalucía: Editorial Almuzara.

Jiménez Jiménez, B. (1986). Didáctica del vocabulario. Barcelona: Humanitas.

Khayat, I. (2016). Algunos aspectos de la influencia del árabe en la lengua española. (Tesis de Grado). Universidad Autónoma de Barcelona. Recuperado de: https://ddd.uab.cat/ pub/tfg/2016/tfg_45415/TFG_2015-16_FTI_Khayat.pdf

Lapesa, R. (1980). Historia de la langua española. Madrid: Gredos.

Lapesa, R. (1984). Los árabes y el elemento árabe en español. Historia de la langua española. (2da edición) (pp. 129-156). Madrid: Gredos.

Lastra (1992). Lenguas en contacto. Sociología de Hispanoamérica. México: UNAM

Lázaro Carreter, F. (1953) Diccionario de términos filológicos. Madrid: Gredos.

López Tamarix, F. (1873).Compendio de algunos vocablos arábigos introducidos en la lengua castellana. En G. Mayans y Sisear (Ed.). Orígenes de la Lengua Española. (2a edición). (pp. 194-213). Madrid: Rivadeneyra.

Llorente Maldonado de Guevara, A. (1991). Los topónimos españoles y su significado. Salamanca: Editorial CE, Universidad de Salamanca.

Maíllo Salgado,F.(1991). Los arabismos del castellano en la Baja Edad Media (consideraciones históricas y filológicas). (2a edición). Salamanca: Universidad de Salamanca.

Maldonado, C. (1977) Diccionario de uso del español actual. Madrid: Editorial SM.

Marcos Maíllo, A. (2003). Los arabismos más utilizados por los conquistadores de nueva España en el siglo XVI. Res Diachronicae, (2), 230-327. Recuperado de https:// resdiachronicae.files.wordpress.com/2013/12/volumen-2-28_marcos.pdf

Marcos Marín, F. (1984). Latín tardío y romance temprano. Revista de Filología Española, 64 $(1 / 2), 130-147$.

McCarthy, M. y O’Dell, F. (2010). Basic vocabulary in use. [Versión digital]. Recuperado de: https://www.scribd.com/doc/316693530/McCarthy-Basic-Vocabulary-in-Use-pdf

Mikinasi, A. (1963). Léxico de las palabras españolas de origen árabe. Madrid: Editorial SM.

Millar C., M. (1998). Los arabismos en la lengua española. Boletín de Filología, 37(2), pp. 781-801. Recuperado de: http://repositorio.uchile.cl/bitstream/handle/2250/134131/ Los-arabismos-en-la-lengua\%20espanola.pdf?sequence $=1$

Millar C., M., Salgado Núñez, R. y Zedán Lolas, M. (2005). Gramática de la lengua árabe para hispanohablantes. [Versión digital]. Recuperado de: https://books.google.com. co/books?id=FE8w5YF7650C\&pg=PA34\&lpg=PA34\&dq=clasificaci\%C3\%B3n+de + las+consonantes+en+arabe \&source=bl\&ots=EUgbFJbaRm\&sig=2hfdbsriwoetUGI _2Amsh4ewee8\&hl=es\&sa=X\&ved=0ahUKEwiXgZiurvDTAhXDXyYKHfETCP0 Q6AEIVzAJ\#v=onepage \&q=clasificaci\%C3\%B3n\%20de\%20las\%20consonantes $\% 20$ en $\% 20$ arabe $\& \mathrm{f}=$ false

Moliner, M. (1998). Diccionario de uso del español. Madrid: Editorial Gredos.

Neuvonen, E.K. (1941). Los arabismos en el siglo XIII. Helsinki: Imprenta de la Sociedad de Literatura Finesa. 
Pavón Maldonado, B. (1977). Crónica arqueológica de la España musulmana Al-Ándalus, Revista de las Escuelas de Estudios Árabes de Madrid y Granada, 42, fasc. 1, 207-225.

Pérez Moreta, J. y Viudas Camarasa, A. (1998). Lengua española. Curso de orientación universitaria. Madrid: Ediciones SM.

Quintana, L. y Mora, J.P. (2002). Enseñanza del acervo léxico árabe de la lengua española. En M. Pérez Gutiérrez y J. Coloma Maestre (Eds.). XIII Congreso Internacional de la ASELE. El Español, Lengua del Mestizaje y la Interculturalidad. (pp. 697711). Murcia. Recuperado de: https://cvc.cervantes.es/ensenanza/biblioteca_ele/asele/ pdf/13/13_0697.pdf

Real Academia Española. (2014). Diccionario de la lengua española. (23 edición). Madrid: Espasa.

Rincón Castellanos, C. A. (2012). Propuesta bajo palabra. Universidad de Antioquía. Recuperado de https://media.utp.edu.co/referencias-bibliograficas/uploads/referencias/ ponencia/propuesta-bajo-palabrapdf-ZO3Ly-articulo.pdf

Ruano, E. B. (2002). Tópicos y realidades de la Edad Media. Madrid: Real Academia de la Historia.

Sala, M. (1988). El problema de las lenguas en contacto. México: Universidad Nacional Autónoma de México.

Sánchez Pérez, A. (1982). La Enseñanza de Idiomas, principios, problemas y métodos. Barcelona: Ediciones Hora.

Santano y León, D. (1981). Diccionario de gentilicios y topónimos, Madrid: Paraninfo.

Sola Solé, J. M. (1973). Corpus de poesía mozárabe; las harğa-s andalusies. Barcelona: Ediciones Hispam.

Steiger, A. (1932). Contribución a la Fonética del Hispano-Árabe y de los Arabismos en el Ibero-románico y el siciliano. Madrid: CSIC, Consejo Superior de Investigaciones Científicas.

Toro Lillo, E. (2006) La invasión árabe. Los árabes y el elemento árabe en español. Recuperado de: http://www.cervantesvirtual.com/obra-visor/la-invasin-rabe-los-rabesy-el-elemento-rabe-en-espaol-0/html/00b64db8-82b2-11df-acc7-002185ce6064_2.htm

UNESCOPRESS. (2014). Once nuevos elementos en la lista representativa del patrimonio cultural inmaterial. Recuperado de https://es.unesco.org/news/once-nuevos-elementoslista-representativa-del-patrimonio-cultural-inmaterial

Vázquez de Benito, M. C. y Herrera, M. T. (1989). Los arabismos de los textos médicos latinos y castellanos de la edad media y de la modernidad. Madrid: Consejo Superior de Investigaciones Científicas.

Vernet, C. (1960) Toponimia arábiga. Enciclopedia Lingüística Hispánica, 1. Madrid: Consejo Superior de Investigaciones Científicas.

Wagner, M. (1934). Etimologías españolas y arábigo-hispánicas. Revista de Filolgía Española. $34,225-247$. 
Walsh, J. K. (1967). Supervivencia del árabe s-r-q y g-r-b en el léxico peninsular. Al -Andalus: revista de las Escuelas de Estudios Árabes de Madrid y Granada. 32 (2), 261-275.

Walsh, J. K. (1971). The Hispano-Oriental Derivational suffix -1́. Romance Philology. 25, 159-172. Wijk, H. L. A. (1949). L'élément árabe en espagnol. Neophilologus. 33, 13-23.

Wikipedia, la enciclopedia libre. (s.f.). Idioma mozárabe. Recuperado de: https://es.wikipedia. org/wiki/Idioma_moz\%C3\%A1rabe 